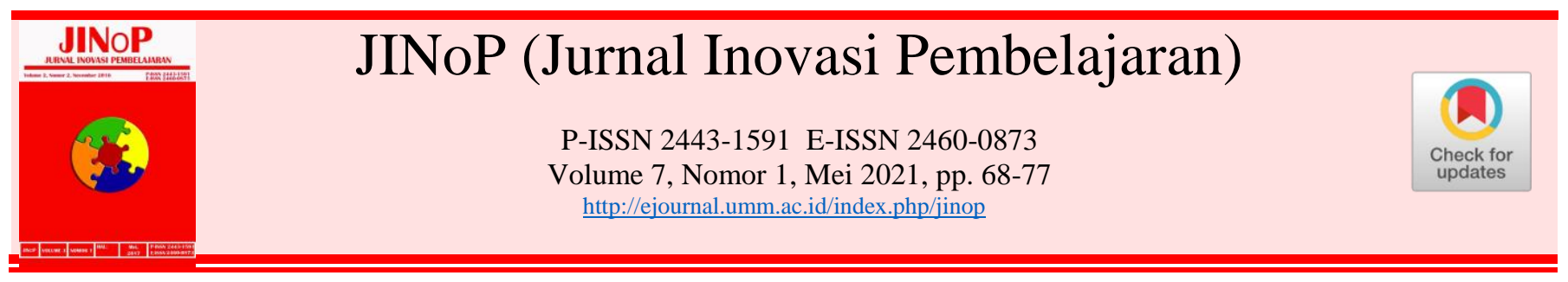

\title{
Implementasi pendidikan karakter berbasis kearifan lokal
}

\author{
Aiman Faiz ${ }^{1)^{*}}$, Bukhori Soleh ${ }^{2)}$ \\ ${ }^{1}$ Pendidikan Guru Sekolah Dasar, Fakultas Keguruan dan Ilmu Pendidikan, Universitas \\ Muhammadiyah Cirebon, Jl. Tuparev No. 70, Cirebon, Indonesia \\ ${ }^{2}$ Pendidikan Guru Sekolah Dasar, Fakultas Keguruan dan Ilmu Pendidikan, Universitas
} Muhammadiyah Cirebon, Jl. Tuparev No. 70, Cirebon, Indonesia

aimanfaiz@umc.ac.id*; bukhori.soleh@umc.ac.id

*Penulis Koresponden

\begin{abstract}
ABSTRAK
Integrasi kearifan lokal dalam bentuk kemampuan membuat batik, melukis kaca, dan pengenalan budaya-budaya khas Cirebon lainnya dalam Mata Kuliah Umum (MKU) dapat menjadi alternatif pembelajaran yang menarik. Penelitian ini bertujuan untuk mendeskripsikan implementasi model pendidikan karakter berbasis kearifan lokal budaya. Contohnya, Penelitian ini menggunakan metode kualitatif deskriptif untuk mengeksplorasi fenomena yang terlihat secara alami. Subjek penelitian ini adalah mahasiswa semester 7 Pendidikan Guru Sekolah Dasar (PGSD), Universitas Muhammadiyah Cirebon (UMC), angkatan 2016. Data diperoleh melalui observasi dan wawancara kepada 15 responden yang terdiri dari mahasiswa, dosen, dan Ketua Program Studi PGSD UMC. Hasil temuan menyatakan bahwa MKU dapat menambah pengetahuan dan keterampilan mahasiswa di luar bidang pendidikan. Terkhusus, mahasiswa merespon budaya Cirebon yang diberikan dalam MKU tersebut dengan antusias. Dapat disimpulkan bahwa MKU berbasis kearifan lokal mampu mengasah skill mahasiswa PGSD UMC agar memiliki kemampuan afektif dan psikomotorik di samping kemampuan kognitif. Dengan demikian, mahasiswa disiapkan untuk memiliki kemampuan holistik yang siap dengan tantangan kehidupan baru.

Kata Kunci: Budaya Cirebon; Kearifan Lokal; Pendidikan Umum
\end{abstract}

ABSTRACT
The integration of local wisdom, such as batik and glass painting, and other Cirebon culture in
general courses (Mata Kuliah Umum/ MKU) may be an interesting alternative learning approach.
This research aims to describe the implementation of character education models based on local
cultural wisdom such as the ability to design batik, glass paintings, and the introduction of other
typical Cirebon cultures in MKU. It employed a descriptive qualitative approach to explore
naturally visible phenomena. The subjects of this research were 7th semester students of Primary
School Teacher Education (Pendidikan Guru Sekolah Dasar/ PGSD), University of
Muhammadiyah Cirebon (UMC), class of 2016. The data were obtained from observations and
interviews involving 15 respondents consisting of students, lecturers, and the Head of PGSD
UMC. The results showed that MKU increased students' knowledge and skills outside the field
of education as the students were enthusiastically embraced the Cirebon culture given in MKU.
It can be concluded that MKU based on local wisdom was able to hone the skills of PGSD UMC
students in improving their affective, psychomotor, and cognitive abilities. Thus, students were
prepared to have holistic abilities that are compatible with the challenges of a new life.
Keywords: Cirebon Culture; Local Wisdom; General Education
diunggah: $2020-11-09$, direvisi: 2021-01-26, diterima: 2021-04-23, dipublikasi:2021-05-22.
Copyright (c) 2020 Faiz et al
This is an open access article under the CC-BY license
cC (1)


Cara sitasi: Faiz, A., \& Soleh, B. (2021). Implementasi pendidikan karakter berbasis kearifan lokal. JINoP (Jurnal Inovasi Pembelajaran), 7(1), 68-77. https://doi.org/10.22219/jinop.v7i1.14250

\section{PENDAHULUAN}

Nilai kearifan lokal menjadi hal yang dikhawatirkan akan punah di tengah perkembangan zaman (Faiz et al., 2020). Banyak gejala yang menunjukkan bahwa para kalangan muda lebih memilih dan tertarik pada budaya asing. Seyogyanya, generasi muda harus menjadi tulang punggung dalam mempertahankan eksistensi kearifan lokal. Untuk mencapai hal tersebut, diperlukan penguatan agar kecintaan terhadap nilai kearifan lokal kembali tertanam dalam diri generasi muda.

Pembudayaan nilai-nilai kearifan lokal bermuatan karakter memiliki tingkat efektivitas yang tinggi. Faiz (2019) mengatakan bahwa praksis pembelajaran menjadi tempat yang sangat representatif dalam penanaman nilai-nilai karakter. Dalam hal ini, kearifan lokal dapat diintegrasikan dalam proses pembelajaran, ekstrakurikuler, atau kegiatan lainnya (Nadlir, 2014; Prastowo, 2015). Dalam ranah perguruan tinggi misalnya, Ristekdikti sudah mengupayakan pembudayaan nilainilai kearifan lokal yang diimplementasikan melalui rumusan kurikulum, baik yang berbasis Kerangka Kualifikasi Nasional Indonesia (KKNI) maupun Merdeka Belajar. Hal ini bertujuan agar pendidikan dalam lingkup perguruan tinggi mempertimbangkan kondisi dunia yang berubah pesat dengan berbagai faktor pendorongnya, termasuk perkembangan arus revolusi industri pada bidang IPTEK (Rachmat Bin Badani Tempo \& Aqbar, 2020; Ristekdikti, 2017). Di samping dampak positif, revolusi industri pada era ke-4 ini pun memberikan dampak negatif, terlebih hal yang bersinggungan dengan nilai kearifan lokal yang dikhawatirkan akan terganti dengan nilai-nilai global.

Oleh sebab itu, sentuhan inovasi dari perguruan tinggi sangat diperlukan sebagai respon untuk meningkatkan memperbaiki dan meningkatkan kualitas lulusan. Indikator pokok lulusan harus mampu mengembangkan konsep-konsep pendidikan yang memfokuskan pada pengembangan nilai dan karakter (Ristekdikti, 2017). Dengan kata lain, pendidikan tinggi harus mempersiapkan mahasiswa untuk terampil dalam segala hal, termasuk dalam kemampuan di bidang industri kesenian berbasis kearifan lokal.

Program studi Pendidikan Guru Sekolah Dasar (PGSD) Universitas Muhammadiyah Cirebon (UMC) mewajibkan para mahasiswanya memiliki kemampuan di bidang industri kreatif berbasis kearifan lokal daerah Cirebon. Di antaranya, membuat batik, melukis di atas kaca, pengembangan bahan pangan lokal Cirebon, dan pengenalan budaya Cirebon lainnya. Pengembangan karakter mandiri dan kreatif ini diimplementasikan pada Mata Kuliah Umum (MKU) semester 7.

Pengembangan karakter berbasis kearifan lokal ini ini merupakan upaya mempersiapkan remaja pada era globalisasi dengan membangun karakter dan kecintaan pada nilai budaya kearifan lokal. Dalam hal ini, kearifan lokal merupakan sumber nilai, yang berlandaskan pada tradisi sehingga menjadi filosofi hidup yang dipegang teguh oleh penganutnya guna menjalankan keberlangsungan generasi adat. Hal tersebut merupakan pedoman dan ilmu pengetahuan dengan berbagai strategi yang diterapkan oleh masyarakat lokal dalam memenuhi kebutuhan pengikutnya (Fajarini, 2014). Sedangkan, menurut Nurrochsyam (2011) kearifan lokal memiliki arti yang multitafsir, di mana secara garis besar dapat diartikan sebagai konsep-konsep makna gagasan yang dimiliki suatu tatanan masyarakat. 
Apabila tidak dibudayakan, nilai-nilai kearifan lokal akan luntur yang berakibat pada degradasi moral bangsa. Dalam hal ini, kebaikan moral menjadi falsafah hidup masyarakat, dan pemandu untuk menjalankan proses kehidupan. Jika nilai kearifan lokal menurun, hal tersebut menjadi ancaman terhadap eksistensialisme suatu generasi (Wibowo \& Anjar, 2017). Maka, perlu adanya rekonstruksi pendidikan dalam perguruan tinggi untuk mengembangkan nilai, karakter dan kemampuan tambahan untuk mencegah hal tersebut.

Membekali mahasiswa dengan keahlian tambahan merupakan ciri dari pembelajaran abad-21 yang menekankan pada kemampuan 4C, yaitu communicative (komunikasi), creative (kreatif), collaborative (kolaboratif) dan critical thinking (berpikir kritis). Untuk itu, proses pembelajaran yang berfokus pada kreativitas akan melahirkan pribadi yang inovatif dan memiliki kemampuan kewirausahaan yang memperhatikan kearifan lokal masyarakat setempat.

Sumber Daya Manusia (SDM) unggul diharapkan dapat memecahkan berbagai problema yang ada. SDM unggul yang mampu berwirausaha dan berpikir kritis) dapat dilahirkan dari sistem pendidikan yang bertujuan menyiapkan mahasiswa siap kerja (employment oriented) dengan capaian skill tertentu. Selain itu, konsep (enhanced and expanded talents) juga diperlukan untuk meluaskan keahlian dan kompetensi yang dimiliki mahasiswa maupun peserta didik (Tilaar, 2016).

Dengan demikian, sebuah konsep besar harus dirumuskan oleh dunia pendidikan Indonesia agar mampu mengembangkan berbagai keahlian yang mencakup kreativitas dan kemampuan berpikir kritis, Hal ini akan menghasilkan luaran lulusan yang unggul. Melalui Mata Kuliah Umum (MKU), PGSD UMC menawarkan local pride berbasis kearifan budaya lokal yang mengacu pada KKNI. Hal ini sesuai dengan semangat kurikulum yang berlandaskan pada konsep filsafat progresivisme yang mengacu pada pengetahuan baru, yang bisa dikembangkan oleh para pemangku kebijakan di perguruan tinggi (Faiz \& Kurniawaty, 2020) .

\section{METODE}

Penelitian ini berlokasi di PGSD UMC dengan mengambil konsep pendekatan kualitatif. Pendekatan ini bertujuan untuk mengamati objek secara alamiah, baik dengan teknik observasi maupun wawancara. Sugiyono (2007) mengungkapkan bahwa penelitian kualitatif dapat mengamati fenomena tertentu yang dirasakan oleh subjek penelitian secara empiris mencakup perilaku, persepsi, motivasi maupun tindakan. Hasil pengamatan dideskripsikan dalam bentuk katakata dan bahasa pada suatu konteks khusus dengan memanfaatkan metode yang alamiah (Sugiyono, 2007) yang tidak dimanipulasi keadaan dan kondisinya (Arikunto, 2007) .

Subjek penelitian berjumlah 15 orang yang terdiri dari mahasiswa semester 7 (pada tahun 2019), seorang dosen pengampu MKU, dan kaprodi PGSD UMC. Melalui wawancara dan observasi, studi secara intensif, terinci, dan mendalam dilakukan terhadap implementasi pendidikan karakter berbasis kearifan lokal dalam MKU prodi PGSD UMC selama satu semester.

Analisis data terhadap jawaban mahasiswa berlangsung pada saat pengumpulan dan setelahnya. Karena beberapa hasil analisis belum memuaskan, peneliti melakukan wawancara kembali untuk memperoleh kredibilitas (Cohen et al., 2016; Miles \& Huberman, 1992). Analisa data dilakukan secara interaktif dan berkelanjutan sampai data tersebut tuntas dan jenuh, atau jawaban serupa. Hal ini didapatkan melalui proses reduction (reduksi data), data display (penyajian data), dan 
data conclusion drawing/ verification (penarikan kesimpulan) (Gambar 1) (Sugiyono, 2013). Data yang terkumpul menjadi dasar penyusunan model implementasi pendidikan karakter berbasis kearifan lokal.

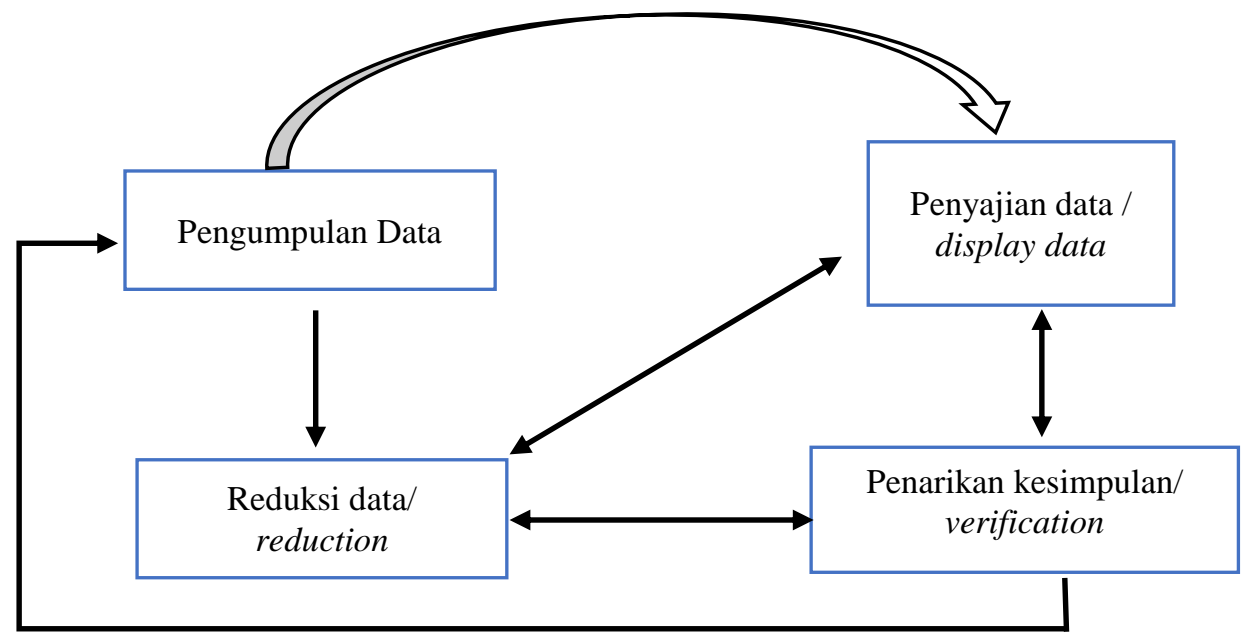

Gambar 1. Alur analisis data

\section{HASIL DAN PEMBAHASAN}

\section{Implementasi nilai kearifan lokal dalam Mata Kuliah Umum (MKU)}

PGSD UMC memiliki satu MKU yang berkaitan dengan kearifan lokal daerah Cirebon, yaitu membuat batik, melukis di atas kaca, pengembangan bahan pangan lokal Cirebon, dan pengenalan budaya Cirebon lainnya. MKU berbasis kearifan lokal budaya Cirebon ini menjadi salah satu upaya pembekalan mahasiswa agar memiliki kemampuan dan daya saing di tengah kemajuan zaman. Sehingga mahasiswa tidak antipati terhadap budaya lokal yang ada di mana budaya lokal Cirebon terus terpelihara dalam lingkup pendidikan tinggi.

Berdasarkan hasil wawancara dengan ketua Prodi PGSD UMC, direalisasikannya MKU berbasis kearifan lokal mengacu pada kondisi zaman yang semakin kompetitif, sehingga tidak cukup apabila lulusan hanya memiliki kemampuan di bidang keguruan saja. Lulusan perlu dikembangkan sehingga memiliki kemampuan di bidang enterpreneurship yang dibutuhkan saat ini. Temuan ini menandakan bahwa PGSD UMC telah berhasil melakukan inovasi pembelajaran yang berbasis pada nilai-nilai local wisdom. Hal tersebut sejalan dengan konsep teori yang mengutarakan bahwa kearifan lokal dapat diintegrasikan ke dalam pembelajaran sebagai upaya para pendidik untuk dapat mempertahankan budaya lokal melalui integrasi dan inovasi pembelajaran yang memuat nilai kearifan lokal (Wuryandani, 2010).

Lebih jauh lagi, ketua prodi menjelaskan bahwa konsep pengembangan MKU berbasis kearifan lokal tersebut berdasarkan pada buku yang diterbitkan oleh Ristekdikti (2017) tentang pendidikan yang terintegrasi pada IPTEK. Dengan menghadapi era revolusi industri, pendidikan harus mengimbangi dengan adanya revolusi pemikiran sosial budaya dan Agama. Konsep inovasi yang dikembangkan PGSD UMC mengkolaborasikan antara pengembangan sumber daya manusia dan eksistensi budaya lokal yang harus selalu terpelihara dan terjaga kesejahteraannya.

Pernyataan ketua prodi tersebut diperkuat oleh pendapat Suwardana, (2018) yang menyatakan bahwa perguruan tinggi sebagai agent of change perlu memikirkan dua arah pembangunan (ke luar dan ke dalam). Pembangunan ke luar 
meliputi kesejahteraan, sedangkan pembangunan ke dalam adalah membangun sumber daya manusia. SDM yang memiliki keunggulan akan mengantarkan Indonesia pada persaingan negara maju dan siap mengembangkan pembangunan nasional. Indikator suatu bangsa memiliki keunggulan antara lain mampu mencapai tujuan secara produktif, cepat, kreatif, dan memiliki optimisme. Hal tersebut menjadi salah satu core value PGSD UMC sebagai kampus kreatif dan inovatif.

Proses penanaman kearifan lokal melalui pengembangan MKU secara eksplisit mampu membekali mahasiswa dengan kemampuan 4C. Sebagaimana diungkapkan ketua prodi bahwa (Gambar 2):

"Revolusi industri ini perlu adanya pembaharuan dalam kurikulum pendidikan untuk menstimulus kemampuan berpikir kreatif, kolaboratif mahasiswa."

\section{Gambar 2. Pendapat Ketua Program Studi}

Sehingga dapat disimpulkan bahwa MKU berbasis kearifan lokal membantu mahasiswa menjadi kreatif dalam menuangkan ide dan gagasannya melalui seni dan bahan pangan khas Cirebon.

Berkolaboratif dengan para ahli di bidangnya, salah satunya PGSD UMC bermitra dengan Rumah Batik Trusmi. Pengembangan MKU berbasis kearifan lokal tersebut akan memberikan peningkatan SDM di era revolusi industri ini. Pernyataan ketua prodi tersebut dipertegas oleh Fuadin (2016) yang menyatakan, di era revolusi industri 4.0 perguruan tinggi harus mampu membekali mahasiswa agar mampu berpikir kritis, komunikatif, kolaboratif dan kreatif di era 4.0.

Pengintegrasian kearifan lokal Cirebon dalam hal membatik menunjang mahasiswa melahirkan kemampuan 4C (critical thinking, creative, collaborative, comunicative). Hal ini dijelaskan oleh Iin, salah satu responden, dalam kutipan berikut (Gambar 3):

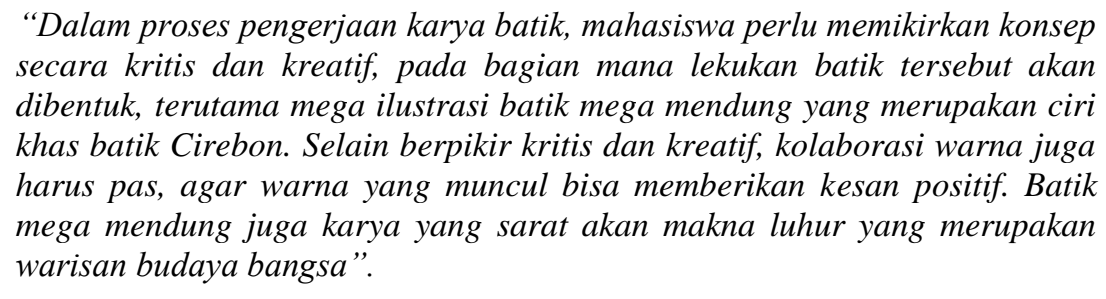
khas batik Cirebon. Selain berpikir kritis dan kreatif, kolaborasi warna juga harus pas, agar warna yang muncul bisa memberikan kesan positif. Batik mega mendung juga karya yang sarat akan makna luhur yang merupakan warisan budaya bangsa".

\section{Gambar 3. Pendapat responden 1}

Kutipan ini sejalan dengan teori yang relevan bahwa kemampuan 4C bisa tercipta melalui MKU berbasis kearifan lokal ini. Digerakkannya kembali konsep pembelajaran berbasis kearifan lokal merupakan sebuah inovasi yang sangat positif ketika para generasi muda mulai enggan mengenali budayanya. Hal ini sesuai dengan peran strategis perguruan tinggi dalam memperbaiki kondisi bangsa melalui kearifan lokal baik secara olah pikir (menjadi cerdas, kreatif dan inovatif), olah rasa (memiliki budi, kehalusan rasa, humanis, toleran, peduli, suka menolong), olah hati (beriman, bertakwa, jujur, adil, amanah, bertanggungjawab, empati) dan olah raga (sehat, disiplin, sportif, tangguh, gigih) (Fuadin, 2016) .

Pentingnya penanaman nilai kearifan lokal melalui MKU ini mendapat respon positif dari mahasiswa PGSD UMC. Sebagian besar mahasiswa masih awam 
terhadap budaya lokal Cirebon. Namun, MKU berbasis kearifan budaya lokal membuka kesadaran mahasiswa PGSD UMC akan pentingnya nilai budaya yang harus dipelihara.

Seorang mahasiswa responden lain mengungkapkan bahwa (Gambar 4):

"MKU berbasis kearifan lokal memberikan efek positif dalam dirinya melalui ilmu pengetahuan. Sebagai mahasiswa, ia tidak hanya mendapatkan aspek kognitif saja, namun juga psikomotor secara learning by doing”. Asep, responden mahasiswa lain, menambahkan bahwa "Mempelajari budaya setempat memperkaya aspek pengetahuan dan keterampilan, dan juga membangun kesadaran mencintai nilai budaya lokal. Secara tidak langsung, dapat diartikan bahwa perkuliahan MKU berbasis kearifan lokal memberikan efek penanaman karakter cinta tanah air di kalangan mahasiswa PGSD UMC".

\section{Gambar 4. Pendapat responden 2}

Hal ini sejalan dengan pemikiran Suyadi (dalam Faiz et al., 2020) bahwa generasi muda harus memiliki kecintaan dan kebanggaan terhadap nilai kearifan lokal, hal tersebut merupakan wujud dari warga negara yang memiliki rasa cinta terhadap tanah airnya agar tidak mudah menerima tawaran bangsa lain yang merugikan bangsa sendiri.

Di sisi lain, dosen pengampu MKU berbasis kearifan lokal mengungkapkan adanya inovasi dari aspek nilai-nilai kearifan lokal yang terintegrasi dalam MKU. Inovasi pembelajaran dalam MKU berbasis kearifan lokal ini merupakan cara untuk membangun karakter bangsa agar generasi penerus memiliki nilai jati diri yang kuat dalam mempertahankan eksistensi kearifan lokalnya. Sebagaimana yang diungkapkan Zaltman dan Duncan (1977 dalam Kristiawan et al, 2018) bahwa adanya inovasi yang dikembangkan untuk merespon situasi sehingga memerlukan proses kreatif untuk menghasilkan sebuah penemuan. Dengan demikian, inovasi yang dikembangkan oleh PGSD UMC bertujuan untuk mempersiapkan generasi muda agar memiliki rasa cinta terhadap budaya kearifan lokal.

Melengkapi temuan berupa hasil wawancara, peneliti mendeskripsikan dasar integrasi kearifan lokal Cirebon ke dalam MKU yang didasarkan pada analisis kebutuhan (needs analysis). Hal ini sejalan dengan teori Bocanegra-Valle, (2016) yang menyatakan bahwa pengembangan kurikulum dan inovasi pembelajaran hendaklah didasarkan pada kebutuhan pembelajar. Dengan demikian, tujuan pembelajaran yang aplikatif dan tepat sasaran akan lebih mudah tercapai.

Model inovasi pembelajaran dalam pelaksanaan MKU berbasis kearifan budaya lokal di UMC terangkum dalam bentuk bagan berikut (Gambar 5): 


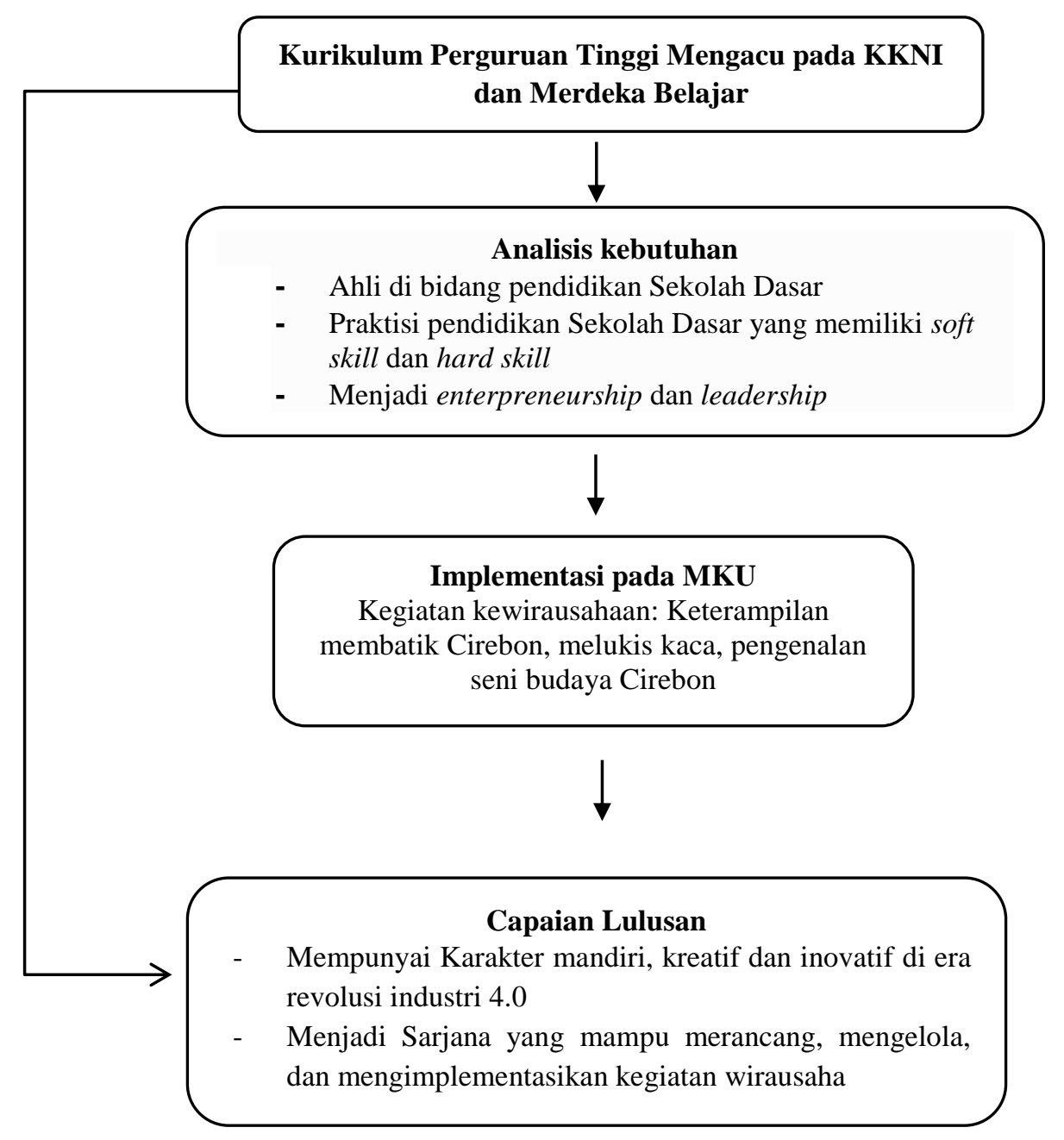

\section{Gambar 5: Paparan hasil analisis}

Dari bagan tersebut, terlihat pentingnya pengembangan kurikulum dalam pendidikan tinggi yang sesuai dengan tuntutan zaman untuk meningkatkan lulusan perguruan tinggi.

Bagan ini dikembangkan berdasarkan hasil analisis dan wawancara dengan ketua prodi, bahwa MKU PGSD UMC dikembangkan berdasarkan pada Kerangka Kualifikasi Nasional Indonesia disingkat KKNI yang diterbitkan pada Peraturan Presiden Nomor 8 Tahun 2012 dan Undang-undang Nomor 12 Tahun 2012 tentang Pendidikan Tinggi. Kerangka tersebut kemudian dikembangkan ke dalam Merdeka Belajar Kampus Merdeka (MB-KM). Hal ini sesuai rumusan konsep Menteri Pendidikan dan Kebudayaan Nadiem Makariem yang bertujuan untuk meningkatkan kompetensi lulusan dari perguruan tinggi agar memiliki kemampuan secara utuh, baik dari aspek soft skill maupun hard skill. Dengan diterapkannya KKNI dan MBKM di jenjang perguruan tinggi, diharapkan mampu mencetak lulusan dengan kualifikasi yang menjadi indikator pada KKNI (Direktorat Jenderal Pembelajaran dan Kemahasiswaan, 2018). .

Hal menarik juga ditemukan pada lingkup kampus UMC di mana pengembangan skill keterampilan membatik, melukis kaca, dan seni budaya Cirebon hanya diterapkan di prodi PGSD UMC. Hal tersebut diungkapkan oleh ketua prodi yang menyatakan bahwa PGSD UMC memiliki program entrepreneur 
dan leadership melalui pengembangan MKU berbasis kearifan lokal yang tidak ditemui di prodi lain pada lingkungan FKIP. Hal ini tentunya menjadi nilai positif bagi PGSD UMC karena telah meramu mata kuliah yang berbasis pada budaya lokal setempat. Praktik inovasi pembelajaran ini dapat menjadi contoh bagi prodi, fakultas, maupun universitas lain agar bisa mengembangkan MKU berbasis kearifan budaya lokal. Hal ini dimaksudkan untuk mengasah skill mahasiswa dan mengembangkan kemampuan secara utuh dalam hal kognitif, afektif, psikomotori, dan bahkan menanamkan karakter cinta nilai budaya lokal.

Inovasi pembelajaran yang dilakukan PGSD UMC juga didasarkan pada konsep utama Mata Kuliah Umum (MKU). Dalam hal ini, MKU bertujuan untuk mengantarkan manusia memiliki kepribadian secara utuh (Direktorat Jenderal Pembelajaran dan Kemahasiswaan, 2018; Ristekdikti, 2017). MKU berpotensi menghilangkan batasan-batasan ilmu karena ilmu dapat diintegrasikan dan saling dihubungkan. Berdasar pemahaman tersebut, MKU dapat berfungsi sebagai wadah ilmu multidisipliner yang harus dimaksimalkan setiap prodi untuk menghasilkan lulusan dengan kompetensi holistik.

MKU berbasis kearifan lokal memberikan pemahaman kreativitas, kemampuan berpikir kritis, entrepreneur dan leadership yang lebih baik sehingga dapat meningkat dibandingkan dengan hanya memberikan teori dan materi yang tidak real atau bersifat simulasi. Hal ini sejalan dengan Wiratno (2012) bahwa prodi perguruan tinggi harus melakukan pembaharuan konsep kurikulum yang orientasinya tidak hanya pada dunia kerja, namun juga kemampuan yang dibekali dengan keterampilan tambahan untuk kehidupan (life skill) dan kemampuan beradaptasi dengan sistem sosial (soft skill). Lulusan diharapkan memiliki rasa ingin tahu agar mampu belajar sepanjang hayat. Dengan metode dan pendekatan yang mampu menghubungkan materi dengan realitas yang ada, akan membuat mahasiswa menemukan sesuatu yang penuh makna (making meaningful conection) (Parhan, 2018; Segal et al., 2002).

Lebih jauh lagi, kemampuan berpikir kreatif, kritis, dan mandiri yang diajarkan dalam MKU PGSD UMC membangun jiwa wirausaha mahasiswa. Pengembangan MKU dapat memperkaya skill mahasiswa yang diperlukan di era 4.0 dan 5.0 agar mampu bersaing di tengah tantangan zaman.

\section{SIMPULAN}

Penerapan KKNI dan pengembangan MB-KM pada MKU berbasis kearifan lokal merupakan bentuk respon PGSD UMC dalam menghadapi tantangan dan kebutuhan zaman agar memiliki kualitas lulusan yang unggul. Integrasi kearifan lokal yang dicontohkan PGSD UMC dapat memberikan pengalaman yang baik bagi mahasiswa. Hal tersebut juga menanamkan nilai cinta kepada budaya setempat, dan mengembangkan kemampuan entrepreneur dan leadership. PGSD UMC menunjukkan peran sebagai agen perubahan yang membekali lulusannya secara komprehensif. MKU berbasis kearifan lokal juga menghapuskan dikotomi keilmuan yang selama ini masih terkotak-kotak, sehingga menegaskan bahwa ilmu bisa terintegrasi satu dengan lainnya.

\section{DAFTAR PUSTAKA}

Arikunto, S. (2007). Evaluasi Program Pendidikan: Pedoman Teoritis Praktis Bagi Mahasiswa dan Praktisi Pendidikan. Bumi Aksara.

Bocanegra-Valle, A. (2016). Needs analysis for curriculum design. In The Routledge Handbook of English for Academic Purposes. 
Cohen, L., Manion, L., \& Morrison, K. (2016). Research Methods in Education, Sixth Edition.

Direktorat Jenderal Pembelajaran dan Kemahasiswaan. (2018). Buku Panduan Penyusunan Kurikulum Pendidikan Tinggi Edisi III. Direktorat Jenderal Pembelajaran Dan Kemahasiswaan Kementerian Riset Teknologi Dan Pendidikan Tinggi, 53(9), 1689-1699. https://doi.org/10.1017/CBO9781107 415324.004

Faiz, A. (2019). Program Pembiasaan Berbasis Pendidikan Karakter Di Sekolah Aiman Faiz karena kualitas karakter menentukan. PGSD Universitas Muhammadiyah Cirebon, 5(20). https://doi.org/10.32534/jps.v5i2.741

Faiz, A., \& Kurniawaty, I. (2020). Konsep Merdeka Belajar Pendidikan Indonesia Dalam Perspektif Filsafat Progresivisme. Konstruktivisme : Jurnal Pendidikan Dan Pembelajaran. https://doi.org/10.35457/konstruk.v12i2.973

Faiz, A., Kurniawaty, I., \& Purwati. (2020). Eksistensi nilai kearifan lokal kaulinan dan kakawihan barudak sebagai upaya penanaman nilai jatidiri bangsa. Jurnal Education and Development Institut Pendidikan Tapanuli Selatan, 8(4), 2730. https://doi.org/https://doi.org/10.37081/ed.v8i4.2067

Fajarini, U. (2014). Peranan Kearifan Lokal Dalam Pendidikan Karakter. Jurnal Sosio-Didaktika: Social Science Education Journal.

Fuadin, A. (2016). Kontribusi Pembelajaran Bahasa Indonesia di Perguruan Tinggi dalam Menghadapi Masyarakat Ekonomi Asean. Semantik: Jurnal Ilmiah Program Studi Pendidikan Bahasa Dan Sastra Indonesia, 5(1), 1-11.

Kristiawan, M., Suryanti, I., Muntazir, M., Ribuwati, A., \& AJ, A. (2018). Inovasi Pendidikan. Wade Group National Publishing.

Miles \& Huberman. (1992). Analisis data kualitatif: Buku sumber tentang metodemetode baru (Tjetjep Rohendi Rohidi (ed.)). UI Press.

Nadlir. (2014). Urgensi Pembelajaran Berbasis Kearifan Lokal. Jurnal Pendidikan Agama Islam, Volume 02, 300-330.

Nurrochsyam, M. W. (2011). Tradisi Pasola antara Kekerasan dan Kearifan Lokal. Kementerian Kebudayaan dan Pariwisata Republik Indonesia.

Parhan, M. (2018). KONTEKSTUALISASI MATERI DALAM PEMBELAJARAN. ADI WIDYA: Jurnal Pendidikan Dasar, Volume. 3,(April), 7-18.

Prastowo, A. (2015). Menyusun Rencana PelaksanaanPembelajaran (RPP) Tematik Terpadu Implementasi Kurikulum 2013 untuk SD/MI. Kencana.

Rachmat Bin Badani Tempo, \& Aqbar, K. (2020). Ikhtiar Mahasiswa KKN STIBA Makassar dalam Pembentukan Akhlak Qur'ani Masyarakat Desa Balassuka Kabupaten Maros. WAHATUL MUJTAMA': Jurnal Pengabdian Masyarakat, 1(1). https://doi.org/10.36701/wahatul.v1i1.151

Ristekdikti. (2017). Memandang Revolusi Industri Dan Dialog Pendidikan Karakter Di Perguruan Tinggi Indonesia. Direktorat Jenderal Pembelajaran dan Kemahasiswaan Kementerian Riset, Teknologi, dan Pendidikan Tinggi.

Segal, G., Borgia, D., Schoenfeld, J., Segal, G. ; \& Borgia, D. ; (2002). Using Social Cognitive Career Theory to Predict Self-Employment Goals Recommended Citation. In New England Journal of Entrepreneurship (Vol. 5, Issue 2). http://digitalcommons.sacredheart.edu/neje/vol5/iss2/8

Sugiyono. (2007). Metodologi Penelitian Pendidikan Kuantitatif, Kualitatif dan $R \& D$. Alfabeta.

Sugiyono. (2013). Metode Penelitian Kuantitatif, Kualitatif dan R \& D. Bandung: Alfabeta. April 2015, 31-46. https://doi.org/10.1017/CBO9781107415324.004 
Suwardana, H. (2018). Revolusi Industri 4. 0 Berbasis Revolusi Mental. JATI UNIK: Jurnal Ilmiah Teknik Dan Manajemen Industri, 1(1), 102. https://doi.org/10.30737/jatiunik.v1i2.117

Tilaar, H. A. R. (2016). Pedagogik teoritis untuk Indonesia. Kompas Media Nusantara.

Wibowo, A., \& Anjar, T. (2017). Internalisasi Nilai Kearifan Lokal (Local Wisdom) Dalam Pelaksanaan Konseling Multikultural Dalam Pengentasan Masalah Remaja Akibat Dampak Negatif Globalisasi. Proceeding Seminar Dan Lokakarya Nasional Bimbingan Dan Konseling 2017, 1(0), 1-9.

Wiratno, S. (2012). Pelaksanaan Pendidikan Kewirausahaan di Pendidikan Tinggi. Jurnal Pendidikan Dan Kebudayaan, 18(4), 454. https://doi.org/10.24832/ jpnk.v18i4.101

Wuryandani, W. (2010). Integrasi nilai-nilai kearifan lokal dalam pembelajaran untuk menanamkan nasionalisme di sekolah dasar. Proceding Seminar Nasional Lembaga Penelitian UNY, 1-10. https://doi.org/10.1017/CBO97811 07415324.004 